\title{
Mughal Seed in Modern Architectural Decoration
}

\author{
Rohita Sharma and Ila Gupta
}

\begin{abstract}
Mughals are not required to any introduction. Their glory, living style, beautiful architecture with its unique decoration is known to all. Babur was the founder of Mughal dynasty. They made very attractive architecture in India. The architectural decorations reflect the taste, interest, livingstandard style and customs of Mughals. These monuments are world famous for its beautiful wall decoration. The contemporary mural decoration has its roots in Mughal art. Inlay, painting and stucco decoration in Mughal era has a unique place in this content. Not only Indians but many foreigners are also impressed from this art. In present time this art has been used on the façade of modern architecture. Before Mughals, Indian architecture was colourless. This contribution goes to the Mughals who brought new techniques with beautiful colours in India. This paper is an attempt to find cultural and aesthetic values for using different techniques and motifs for wall decoration in contemporary period. The objective of the study is to have a better understanding of the influence of Mughal art culture on career, employment, livelihood and social innovation. Apart from the above objectives, this paper tries to find out the answer of several questions, like why do foreign delegates are attracted towards Mughal art and culture. Why do different hotels and restaurants want to resemble with Mughal art? What is the social function of artistic and cultural creativity? On the whole this paper is based on Mural decoration during Mughal era. By the end of this paper it will be clear that what type of mural decoration was used in Mughal era, its history, style, aesthetic pleasure, importance and impact on contemporary art and architecture. The study concludes that the mural decoration in present time has its root from Mughal (Persia).
\end{abstract}

Keywords--- Mural Design, Architecture Aesthetic Pleasures, Commercial

\section{INTRODUCTION}

A RT and architecture are the two faces of same coin. Architecture is the mother of art, sculpture, painting and the allied decorative arts, and further it is a continuous evolution [1]. No one can think about one face of this coin alone because Art also plays an important role in architecture. Utility, Stability and beauty are three imperative elements of the art. Lack of one of these elements creates disability for architecture. "Art is not stone, brick, words, or tricks of trade;

R. Sharma, Research Scholar, HSS Department, IIT Roorkee, India. Email:rohitasharma2009@gmail.com

Gupta Ila, Associate Professor, Architecture \& Planning Department, IIT, India. it is above all the reflection of artist's soul, the visible expression of the forces which drive him" [2]. As mentioned above, art means ' $k a l a$ ' or performing art as singing dancing and painting. Painting can be classified as Miniature and Mural. A mural is a type of work or decoration painted or applied directly on a wall, ceiling or other permanent surface by an artist. "When first the architect opened to the painter, the door of a recently finished edifice, and showed him the walls which were to be adorned by his skill an elevated art arose, the essential principles of which were at once defined by the conditioned of this union. This art may be called Mural or monumental painting" [3]. In all the arts of a country which help to reflect the soul of their patron architecture stood straight forwardly and without any exertion. In present time the term became wider, Frescos, Glazed brick or Tile decoration, Mosaic, Ceramic Decoration, Glazed Earthenware Relief, Enamel, Wood Work, Wood Carving, Inlaying, BurntWood Work, Ornamental-Carpentry, and Mixed Methods are different technique of murals [3]. Mural is the ancient art of India. Ajanta, Ellora, and Bagh are the most gradient example of mural decoration. Almost all the states of the Indian union have mural painting belonging to successive centuries. These paintings or art throw a flood of light on regional culture and art traditions. So these murals play an imperative role to be acquainted with history. But in starting of medieval period many Muslim rulers invaded India and destroyed about all the temples and decoration on it, so there are fewer examples in present. In $15^{\text {th }}$ century Mughal invaded India. All the Mughal emperors were fond of art and nature. They gave a new platform to develop these arts with the help of Indian artisans. This has been continuing in present period.

\section{MUGHal DYNASTY}

The supremacy of Mughal dynasty is gone. The court and respected slogans chanted by their followers is no more. However their physical appearance is not here but their soul is present through the decoration as it is called that they have their power in famous monuments. They were not Indians still they enriched the height of Indian architecture and its decoration. Perhaps this power of art came in their decoration due to cosmopolitan characteristic which has been forced by geographical changes. Mughal have their route from Persia, where Persian traditional art and living survived. The Mughal ruler reigned India from 1526 to 1858 . The founder of the Mughal dynasty in India was Babur. After him, his son Humanyun, ruled from 1530-1543, but due to some attack he ran to Persia and in 1555 he again took the power in his hand. In 1556 he died and Akbar his son seated on the throne. In his time he spread love and peace. Jahangir, Shanjahan and Aurangjeb were the next rulers of Mughal dynasty. 


\section{MUghal Mural DeCORATION}

Babur was the grandfather of Akbar and came to India in $15^{\text {th }}$ century. "There was a battle between Abraham Lodi (the last of the Afgan kings of Delhi) and Babur [4]. "In 1506 Babur paid his visit to Heraat, the residence of his uncle Husayn Byqara. He was fascinated by Heraat, and his descriptions of the city still make interesting reading today. There was a pavilion with mural depicting the heroic deeds of the Timurind Abu-Said Mirza. Later during the Mughal regime, murals were prominent features of castles and palaces" [5]. Babur had brought two Persian artists with him. They had continued doing art work even after the death of Babur. Under the supervision of two artists of Iran and the great Khurasani painter Bihzad, Humayun established an atelier at his court and patronized the Persian style of painting which continued to be evolved till the region Sahanjahan. After the death of Humanyun, his son Akbar took the power in his hand. The tradition of employing artists from abroad was continued. The artists were doing fine work influenced by local culture, climate, tradition, material and technology. They respected others view and want to implement their own style with the help of them. The Mughal were inspired by Persian art and they had applied this art in many Mughal monuments in India, in the form of geometrical and other shapes.

"Different types of mural decorations have been used in Mughal monuments. These are tile decoration, mosaic, painting, stucco, incised and inlay" [6]. Main Contribution goes to the Great Akbar. He was born in India and has deep feelings about his own birth place. He respected all the religion as Hindu, Jain, Sufi and Christian so that it was very easy to prove himself as the best ruler. He wanted to complete his ancestor's dream of "ruling whole India", so he spread love in the form of Din-I-Illahi. He married to a Hindu Rajput girl to make strong relations with Rajputs. Due to his love towards the other religions, the people loved him very much. The most popular mural styles are inlay, tile, stucco and mosaic. Inlay is one of the most popular of them. This was known as Pietra-Dura (Stone-Hard). This art was related to Persia and adopted by the Mughals. The very first example was found in the Ashrafi-Mahal and Tower of victory at Mandu [7]. Due to this point some scholars believe that this art is an ancient art of India but before Mughal invasion to India some Persian artists were already residing in Gujarat by changing their names. These Persians were working as an artist and added some inlay mural decoration in their paintings. By those painting's motifs inlay decoration had been used in the form of architectural decoration. "Akbar invaded these artisans from Gujarat where they were practicing their traditional art. He employed them and provided full freedom to apply their art" [1]. It can be seen in Buland Darwaza, Fathepur Sikri and Delhi Gate and in Jahangiri Mahal of Agra Fort.

In the time of Jahangir regime, this art reach its zenith. The most popular example of this art is The Tomb of Itimad $-U d-$ Daulla near Jamuna in Agra. Jahangir was the lover of art, but indulged himself in drinking wine [8]. There are some motifs of vine vessels, perfume bottles, dishes and flower vase. The complete building looks like a jewel box decorated with many different precious stone. Most of the motifs used in this building have been taken from Persia because the daughter of Itimd-ud-dulla and wife of Jahangir, Nurrzahan was a Persian lady and most of the artists were Persian. "During his period many Safavid artists e.g, Aqa Riza, Ghulam, emigrated from Safavid lands to the court of Jahangir" [9].

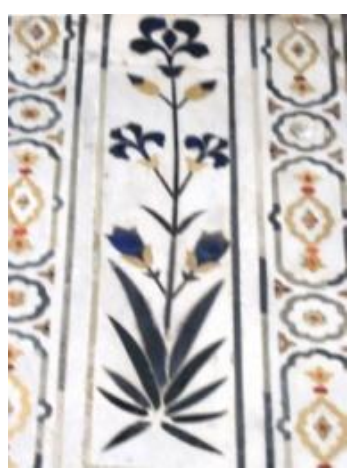

$1 \mathrm{a}$

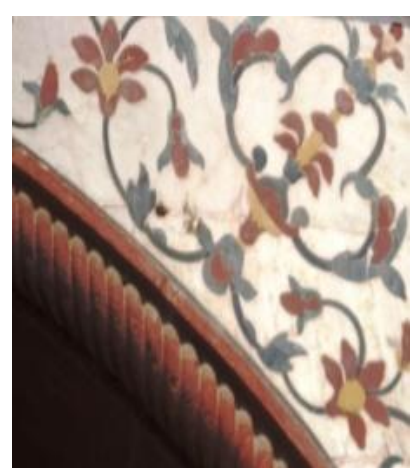

$1 b$
Figure 1: Inlay Decoration in the Tomb of Itimad-ud-Daulla and Taj Mahal

Taj-Mahal is the world famous monument built by Shan Jahan. He was very affectionate of architecture than paintings. Alone Shan-Jahan made many monuments in India with beautiful mural decoration. He was very much impressed by his ancestors as Babur and Akbar. The very first garden laid by Babur in India was Ram Bagh at Agra. "Shan Jahan loved to hear the passages from Babur-Nama the inspiring memories of his great-great grandfather [10].

Besides inlay Mughals art makes use of stucco as a decorative means in mosques and palaces. Indian architecture knows stucco as a material for sculpture in architectural context. History of tile (glazed brick), manufacture and decoration in Persia, goes back to the prehistoric period. It has an important position among the various decorative arts in Persian architecture. Mughal brought this art in India. "The new motifs revolutionalized the whole art. Iranian influence gave a new interpretation to the ancient art of Indian painting" [7].

\section{SUBJeCt MATTER AND THEME}

The subject is divided into different categories as geometrical motifs, arabesque, calligraphy, flora and fauna and many motifs from Hindu mythology. Flora and fauna has importance in all categories and this has many reasons. The very first reason is that the Mughals were very much impressed by the Persian style. Mughals were the first who introduced paradise gardens under Persian inspiration [11]. Mughals adopted their theme of paradise effect. They have used different types of geometrical shapes and in the middle of these shapes they have placed a seat for the majesty so that they could feel themselves in paradise with natural beauty. "The theme of this is based on the garden of Mughal period, inspired by Persian and Indian arts" [12]. The poet Kalim also points out: 
"They have inlaid stone flower in marble, which surpass reality in colour if not in fragrance, Those red and yellow flowers that dispel the heart's grief, In reality are carnelian and amber" [13].

The second reason is that the Mughal rulers were fond of flowers and natural object and they wanted full embroidery in their clothes as well as tent. Their tents were fully decorated with different motifs in embroidery. They ordered to use these motifs on their walls also. In some monuments the subject has been made according to the ruler's taste as in the tomb of Itimad-ud-dulla.

\section{MURAL IN CONTEMPORARY}

The Dayal Bagh temple in Agra is the holy Samadh decorated with flowers in inlay. The construction of this temple was started in 1904 . This beautiful temple is being constructed in memory of the founder "Radha-Soami Faith". The name Radha-Soami was given out by the Supreme Creator himself [14]. Samadh is a Hindi word. In this organized religion, it does not mean by grave (mazar) or "Tomb" or a memorial (yaadgaar). "An immense marble and granite building is being constructed as both a place of worship and tomb" [15]. The main structure of 110 feet X 110 feet and its height including dome and kalasha will be 193 feet. A platform 55 feet broad runs all around the main structure and height of the plinth is 20 feet above the ground level. The pillars are in octagonal shape and are made of marble monoliths. Each pillar is supported on a carved base of marble and covered with an even more elaborately carved cap of marble. On the northern and southern sides, these carved caps are in front of the octagonal pillars, cylindrical and marble monoliths. The rest is masonry work of brick and stone in line covered with marble slabs.

The whole building looks like a garden. The interior and the exterior walls of the building are decorated with flowers, plants, creeper and trees by inlay and carving, which give the spontaneity. The entrance of the Samadh is decorated by tree and flowers on the upper side. The side walls are also decorated with flower like kena (figure 2a), Lotus, Marigold and many others. The main quality is that wherever we go we find the nature and greenery in the form of stones. The Rose and the Sunflower on the pillar come into view in waiting and welcoming for visitors. Every type of flowers, fruits and creepers are decorated here in carving and inlay work. These flower motifs are in natural, decorative and symbolic conditions.

Colours are also used on relief work, at some places in the temple as in the main place of Samadh. In present time there are some decorative pillars having grape-vine painted in green, yellow and brown colours. May be the intention of using all these things in their art is to show the authenticity and feeling of the nature. One who visits this temple gets the feeling of "close to nature" from these motifs. The roof and the floors are also decorated with flowers. The borders are decorated with creepers and circles. Apart from using creepers and circles, artists have made square and octagonal shapes in the middle. These different designs are fully decorated with different motifs and coloured stones. The monument is a unique monument in itself "its builders hope that when finished it will rival the Taj-Mahal" [19]. Mostly motifs which have been used in modern era are related to Mughal time. The Mughal motifs are world famous due to their uniqueness because they used geometric elements with natural ones and created the best example of harmony of object. The artists are using flora and fauna at the same level as it was used during Mughals period. Now the artists are making these motifs in advance style. They are giving lights and shades in the flower as an artist give in water colour.

This style is enhancing the beauty of this temple. At some places flowers are decorated in natural form with its name in Hindi. In some places it has been decorated with some vani or shabad in praise of Radha Soami faith. Radha Soami name is also written in different languages. (Figure $2 \mathrm{~b}$ and $2 \mathrm{c}$ )

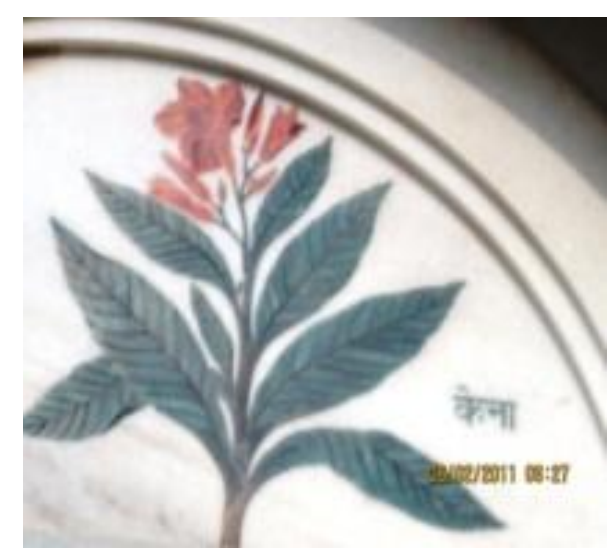

$2 \mathrm{a}$

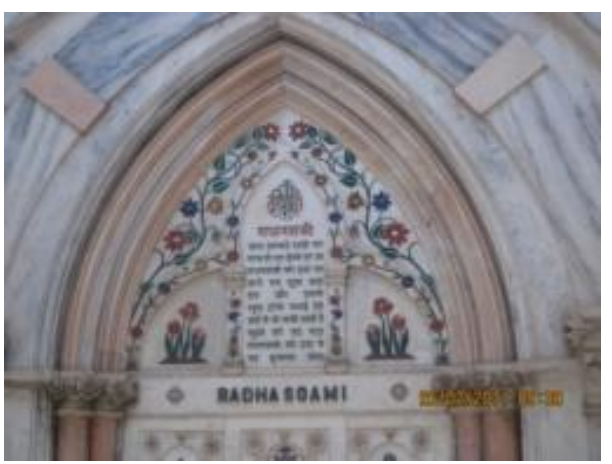

$2 \mathrm{~b}$

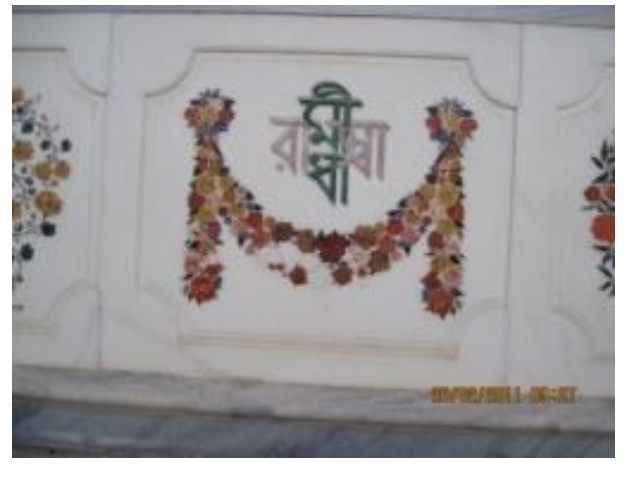

$2 c$

Figure 2: Inlay Decorations in Dayal Bagh Temple 
In the present time inlay is the most popular and usable art. Not only in India but this art is also the point of attraction for foreigners. These foreigners are impressed by the beauty of Mughal inlay decoration. The best example of this is that the American lady Doris Duke came to India for her honeymoon and was so impressed by the inlay decoration of Taj Mahal that she said that she "Had fallen in love with the Taj Mahal and all the beautiful marble tiles with their lovely floral designs with some precious stones". Dories Duke's reaction to the Taj Mahal was so strong that she immediately commissioned a Mughal-Style bedroom and bathroom suite from a British architectural firm" [16]. Her house is decorated with different Islamic decorative items. She visited many different countries and saw different art. But she was so much impressed by the beauty of inlay decoration of Taj Mahal that she took some of the material by shipping from India. Today in India this art can be seen in the many monuments, one of them is the Dayal Bagh temple of Agra, the second is Kalakriti Emporium in Agra, and Nagli Sahib Sakoti-Tanda Meerut.

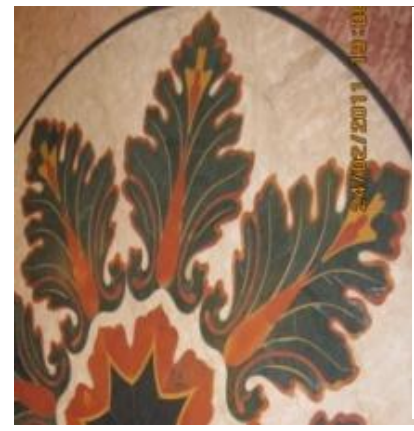

$3 \mathrm{a}$

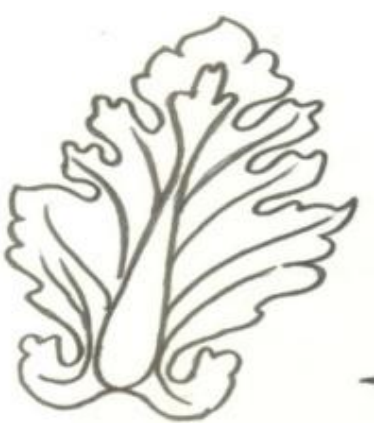

$3 b$
Figure 3: Inlay Decoration of Mughal Motifs in Kala Kriti Emporium

Due to the Taj Mahal being one of the major tourist attractions, there is a flourishing industry of Pietra-Dura artifacts in Agra ranging from tabletops, medallions, elephants and jewellery boxes and other decorative items. This art form is fully alive and thriving in Agra, though the patterns in the designs are more Persian than Roman or Medician. Inlay is also used in many decorative items as Table, chess, pen-stand, plates and many other product of our daily life. Besides this, inlay decoration, tile and stucco style can be easily seen everywhere as residential buildings, shops, and metro subways. "In Fig. 4, different types of inlay decoration can be seen. In Fig. 4a, inlay design made at the table top in bold design is similar to the entrance gate of Tomb of Akbar (Sikandara). In Fig. 4b also, different flowers and colours were used in decorated night lamps which are similar to those used in Red Fort and Taj Mahal. These pictures reveal that the flowers have been used in subjective manner which is the main quality of Mughal era.

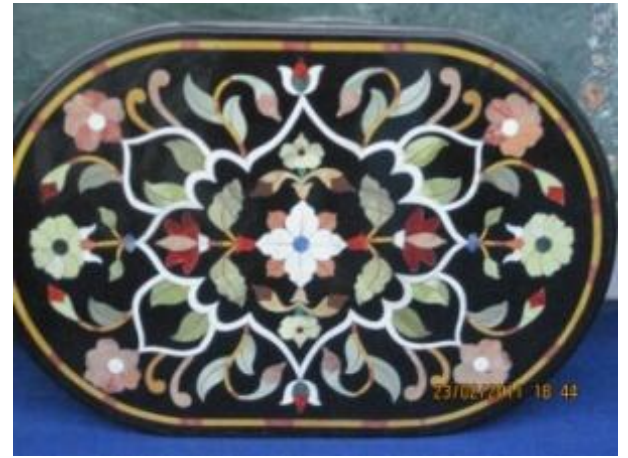

$4 \mathrm{a}$

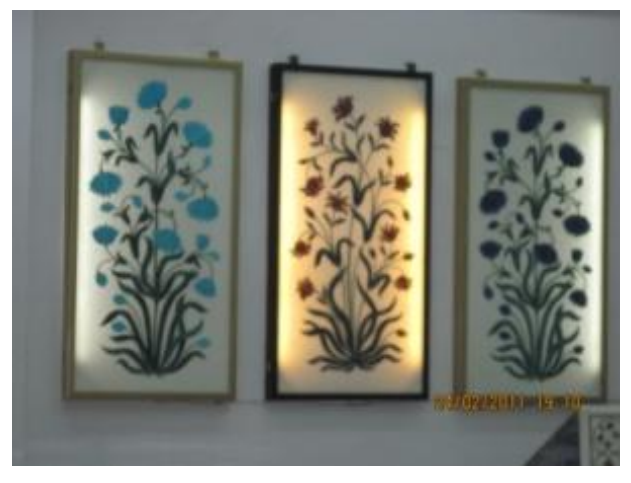

$4 b$

Figure 4: Decorative Tabletop and other Decorative Items in Contemporary Period

\section{IMPACT ON CAREER}

Mural is essential element of the art in present time because everyone wants something distinctive and luxury for himself. People are so busy and they like this decoration due to its durability. The other main point is that murals break the monotony of a boring surface and adds aesthetic pleasure in that with harmony of colours, forms, rhythm of lines and unity. Many foreigners are attracted to Indian murals because of its blend of different arts. These foreigners want to use this style in their home also but due to limited number of the artists, they have to carry by shipping. Many workers or artisans working in this field said that this art is their ancestor's art. In an interview with these artisans they said that their parents were the employees in Mughal era and this skill is transferred to one generation to next generation. They don't have any degree or diploma for this art so that they can work it on high level. In the present time they have developed it as their career. Some workers may start their own contracting businesses. 


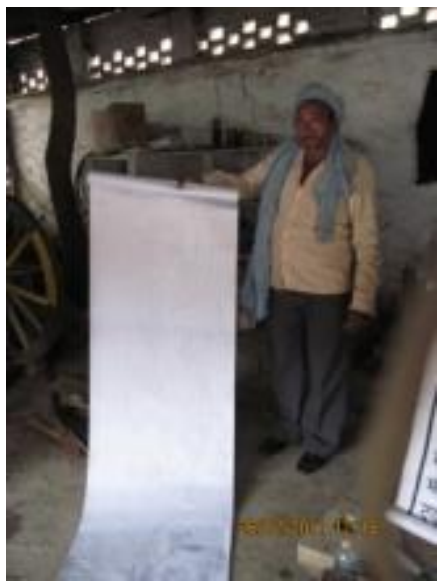

$5 a$

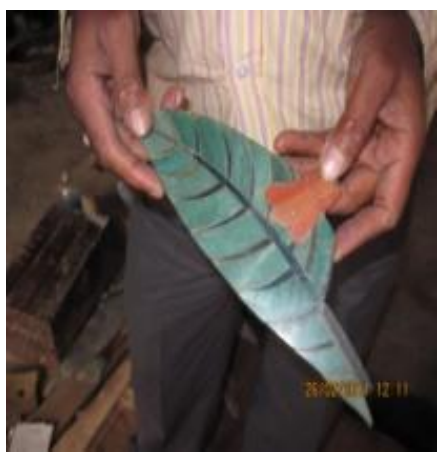

$5 b$

Figure 5: An Artist Showing his Work

\section{CONCLUSION}

In the present time Mughal wall decoration has been used in different places. For example religious places, resorts and hotels and other public places are taking this style to decorate with different motifs as suitable to their places. Mughals have used many type of motifs as animated, natural, geometric and abstract. Many tourists come to India to see the beauty of Taj Mahal and to enjoy the royal life in different hotels with cultural style. Many people are employed with this old tradition. They can earn only for the livelihood to their families. They were doing work with their small equipment. "The Handicraft Industry of Agra is lagging behind to its competitors due to the complete lack of technological advancements in the past few decades"[17] Prahlad Agarwal, chairman of U.P. Handicraft Development Center says that the technology used by the handicraft manufacturers of Agra in preparing their products is decades behind to their contemporaries elsewhere in the world. Besides this fact, still Agra handicrafts attract quality-sensitive buyers from international market but the low production volumes made it difficult for the local handicraft exporters to fulfill large orders in time. The artisans trained their successors by themselves and as a result, the new generation of handicrafts artisans also used the same old technology as their predecessors, leaving no room for the latest technology. He said that the local handicrafts industry had proposed opening a modern stone handicrafts training institute in a joint venture with the local handicrafts industry which could give a chance to the new entrants in this business to develop new handicraft-making skills, but there was no response from the government [17]. Though the Mughals don't exist now but still people are demanding their style in advance techniques. They also want to use inlaid lights in their houses and residential buildings.

To conclude this paper it is clear that culture is the bone of society, it play an important part in the every field as in political or social. Art is not distant from culture. Art has great importance to understanding of history and culture of this great country. Mughal ornamentation influences every person. Even the eye of visitors never blinks while looking different ornamentation of Mughal monuments. Variety of colours theme of different religions different motifs and true devotion of artist made this art world famous.

\section{REFERENCES}

[1] R. Nath, "History of Decorative Art in Mughal Architecture", Pub. Motilal Banarasi Das Delhi, 1976.

[2] A. Godard, "The Art of Iran", Pub. Heron \& Rogers, London, Pp. 254$255,1965$.

[3] A.L. Baldry, "Modern Mural Decoration", Pub London: G. Newnes Ltd, Pp. 4-10, 1902.

[4] H. B. Havell, "A Hand book to Agra and the Taj" Pub. The echo library, Pp.108, 2006.

[5] A. Schimmel, "The Empire of Great Mughal", History, Art and Culture" Pub. Reaktion books L.T.D. London, Pp. 24, 2004.

[6] P. Brown, "Indian panting (Under the Mughals A.D.1550 to A.D.1750) New Delhi: Cosmo, Pp. 19-20, 1983.

[7] R. Nath, "Colour Decoration in Mughal Architecture" Pub. D.B.Taraporvala Bombay, Pp. 49-6, 1970.

[8] H. Beveridge, "The Tuzuk-i-Jahangiri or Memoirs of Jahangir", Tr. Alexander Rogers, Pub. Low Price Publication, Vol.1.

[9] Okada A., and Kesu D., "The Impact of western Art on Mughal painting" Marg, Vol. 49, Issue 4, Pp. 8-19, 1998.

[10] B. Gascoigne, "The great Moghuls" India time books international; publication. New Delhi in Association with Jonathan cape ltd. London, Pp. 153-215, 1987.

[11] P. Jose, "Islamic sacred Architecture: A Stylistic History" |Pub. Books \& books New Delhi, 1994.

[12] R. Sharma, and Gupta I., "A study of Painted Mural Decoration in the Tomb of Sheikh Salim Chisti” IUP journal of Architecture, Vol. 4 , No. 1, Pp 33-43, 2012.

[13] W. Bedley and Z.A. Desai, "Taj Mahal : The Illumined Tomb: An Anthology of Seventeenth-Century Mughal and European Documentary Sources" Pub. Cambridge, Mass. Aga- Khan Program for Islamic Architecture, 1989.

[14] J.N. Farquhar, "Modern Religious Movement in India", Pub. J.S. Cusing Co. Berwick \& Smith Co. Norwood Mass, USA, 1924.

[15] M. Juergensmeyer, "Radha Soami: Reality The Logic of a Modern Faith", Pub. Princeton University Press USA. Pp.15-20, 1991.

[16] S. Littlefield, "The Crossroads of Paradise: Islamic Art in a Hawaiian Home", Marg, Vol. 55, No. 1, Pp. 67-71, 2003.

[17] P. Agarwal, Business Standard, Poor technology hurts Agra handicraft export, available at:http://www.businessstandard.com/india/news/poortechnology-hurts-agra-handicraft-exports, accessed on: 2 November, 2012. 